\title{
EFFECT OF TEMPERATURE, HUMIDITY AND IRRADIANCE ON SOLAR POWER GENERATION
}

\author{
FRANK ONAIFO $^{1 *}$, AKPOFURE ALEXANDER OKANDEJI ${ }^{2}$, OLAMIDE \\ AJETUNMOBI $^{1}$, DAVID BALOGUN ${ }^{1}$ \\ ${ }^{I}$ Department of Electrical and Electronic Engineering, Olabisi Onabanjo University, Ago- \\ Iwoye, Ogun State, Nigeria. \\ ${ }^{2}$ Department of Electrical/Electronic Engineering, University of Lagos, Akoka, Lagos State, \\ Nigeria.
}

\begin{abstract}
This paper studies the effect of temperature, humidity and irradiance on the power generated by a photovoltaic solar cell. This was achieved using pyranometer for determining the solar radiation, wet and dry thermometer for measuring humidity, and digital multimeter for voltage and current measurement. The result of the study show that power generation increases with increase of solar irradiance. Additionally, changes of humidity level and temperature do not significantly affect solar power generation. Furthermore, it was also observed that high temperatures and higher humidity levels accelerate the corrosion process on the solar cells which reduces the efficiency of the cells.
\end{abstract}

Keywords: solar irradiance, humidity, power generation, monocrystalline cells, temperature

\section{INTRODUCTION}

Renewable energy refers to energy obtained directly from nature. Alternatively, renewable energy is energy that is collected from renewable resources which are naturally replenished on a human time scale; example includes sunlight, wind, rain, waves and geothermal heat. Other examples include solar, biomass, energy obtained from tidal waves, energy from flowing water sources, energy obtained from hot springs and biofuels. Amongst the existing forms of renewable energy, solar energy is one of the most fundamental renewable energy sources. Solar energy is radiant light and heat from the Sun that is harnessed using a range of ever-evolving technologies such as solar heating, photovoltaics, solar thermal energy, solar architecture, and artificial photosynthesis amongst others. The importance of solar energy as a fundamental renewable energy is limitless. For example, hydrological cycle important for hydropower generation is controlled by the sun. Wind power is a form of renewable energy where the movement of air is controlled by the heating effect of the Sun. Other examples such as thermal, kinetic, electrical and chemical energy can be obtained through solar energy [1]. In general, they are sometimes called photovoltaic (PV) cells because they make use of sunlight. According to [2], the ambient temperature varies indirectly as the output power performance of the system. Also, [3], using solar cell performance such as short circuit current, open circuit voltage and fill facto, investigated the effect of temperature and irradiance on solar cell performance. Authors in [4] investigated solar irradiance measurement instrumentation and power solar generation forecasting based on Artificial Neural Networks (ANN). Work done by [4] observed that improvements in solar forecasting accuracy can be increased by reducing instrument errors that measure the weather parameters.

\footnotetext{
* Corresponding author, email: frank.onaifo@oouagoiwoye.edu.ng

(c) 2020 Alma Mater Publishing House
} 
Authors in [5] employed the use of camera captured images of the sky to forecast solar irradiance. Work done in [5] monitored the effect of cloud formation on solar irradiance reaching the Earth providing changes in solar radiation over a short term. However, the adopted method was quite sophisticated.

On the other hand, according to [6], irradiance and temperature affect the workings of photocell thereby causing a change in solar power generation. Fill factor, short circuit current, and open circuit voltage was used to measure the performance of a given solar cell. Authors in [7] developed a mathematical model for the solar variation of photocell covering more than one-fifth Earth landmass. Here, the variation over a small area proves difficult to determine. Work done in [8] affirmed that increase in irradiance leads to an increase of short circuit current. It was also shown in [8] that the solar irradiance varies as the solar power output.

In contrast to existing result, this study adopted a simple and low cost method of determining solar irradiance using pyranometer. Humidity and the ambient temperature effect on monocrystalline solar cell is also investigated. The moisture content of the atmosphere is commonly expressed by relative humidity defined as the ratio of actual water vapor pressure contained in air to the saturated water vapor pressure at the same temperature [8]. Air with constant water vapor content will lead to a decrease in relative humidity with a rise in temperature. Water vapor in the atmosphere is invisible to the human eye but it is "received" by solar cells. In particular, this paper investigates the effects of some environmental factors such as temperature, humidity, rainfall on solar cell. Due to the environmental conditions in Nigeria, this research aims to evaluate the effects of temperature, humidity, irradiance on solar cell power output.

\section{EXPERIMENTAL SET UP}

The data collected from solar panel installations located at Olabisi Onabanjo University, College of Engineering and Environmental studies, comprises of information on the solar radiation, temperature and humidity at specific times. In addition, the voltage and current on the Photovoltaic cells to generate the output power at the given time was also obtained.

The Photovoltaic Modules are installed on the terrace of Olabisi Onabanjo University, College of Engineering and Environmental studies, situated at Ibogun Oshungboye, Ifo, Ogun State, Nigeria.

The solar installation consists of solar panels, charge controllers, inverters, and batteries. Each installation is made up of six 24v 300 VA monocrystalline solar panel designed to provide a power output of 1800VA of solar power. The solar panels are connected in parallel with all the positive terminals connected at one end, and the negative terminals connected to the other end. Solar cables are connected to the positive and negative terminals of the solar panel while the other end of the cable is connected to the load terminal of the MPPT solar charge controller (Industrial charge controller). The maximum power point tracking (MPPT) solar charge controller is made up of 4 terminals. Two terminals for solar panel connection and the other two terminals for battery connection. Two $12 \mathrm{v}$ $100 \mathrm{VAH}$ battery is connected in series to obtain $24 \mathrm{v}$ rating of the installation. The two end terminals of the battery are connected to the solar charge controller. The inverter terminals are connected to the two ends of the battery. The inverter rating is $24 \mathrm{v} 2400 \mathrm{VA}$. Pyranometer is used to measure the solar irradiance of the surrounding; wet and dry thermometer is used to measure the humidity. The voltage, current and power measurement was carried out at the solar panel installations in Figure 1 and Figure 2 using digital multimeter.

The humidity comfort level is based on the dew point as it determines whether perspiration will evaporate from the skin, thereby cooling the body. Lower dew points feel drier and higher dew points feel more humid. Unlike temperature, which typically varies significantly between night and day, dew points tend to change more slowly. Accordingly, while the temperature may drop at night; a muggy day is typically followed by a muggy night. Ifo experiences some seasonal variations in the perceived humidity. The muggy part of the year lasts for 11 months, specifically from January 27 to December 25, during which time the comfort level is muggy, oppressive, or miserable at least $85 \%$ of the time. The muggiest day of the year is May 26, with muggy conditions of $100 \%$ of the time. The least muggy day of the year is January 10, with muggy conditions $79 \%$ of the time.

In general, at Ifo, the wet season is overcast, the dry season is partly cloudy, and it is hot and oppressive all year round. Over the course of the year, the temperature typically varies from $71^{0} \mathrm{~F}$ to $92{ }^{0} \mathrm{~F}$ and is rarely below $65{ }^{0} \mathrm{~F}$ or above $95{ }^{0} \mathrm{~F}$. 


\subsection{Materials}

The equipment's used include the pyranometer, used for measuring solar radiation, wet and dry thermometer for measuring humidity, and digital multimeter for measuring voltage and current.

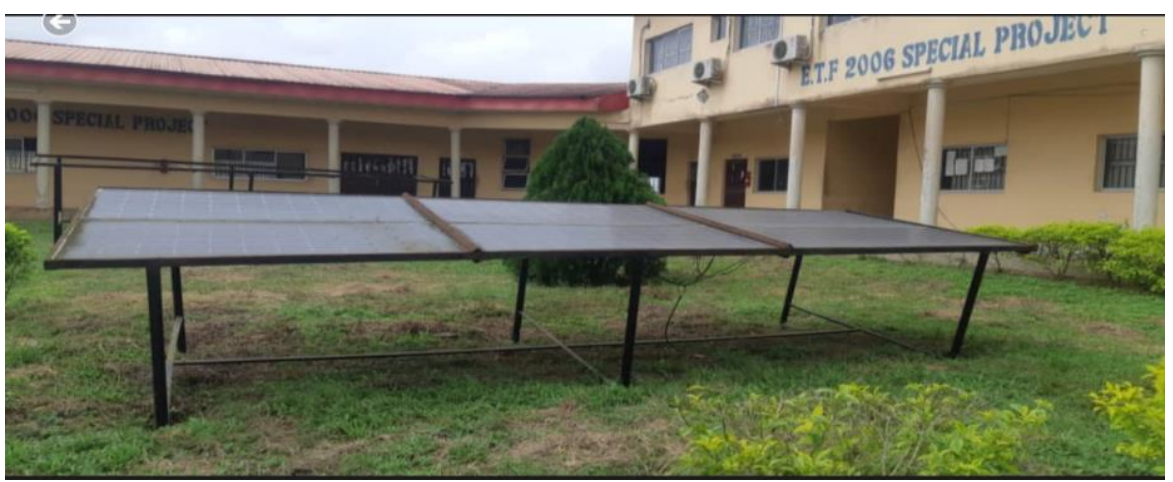

Fig. 1. One of the Solar stand with solar panels used for the experiment.

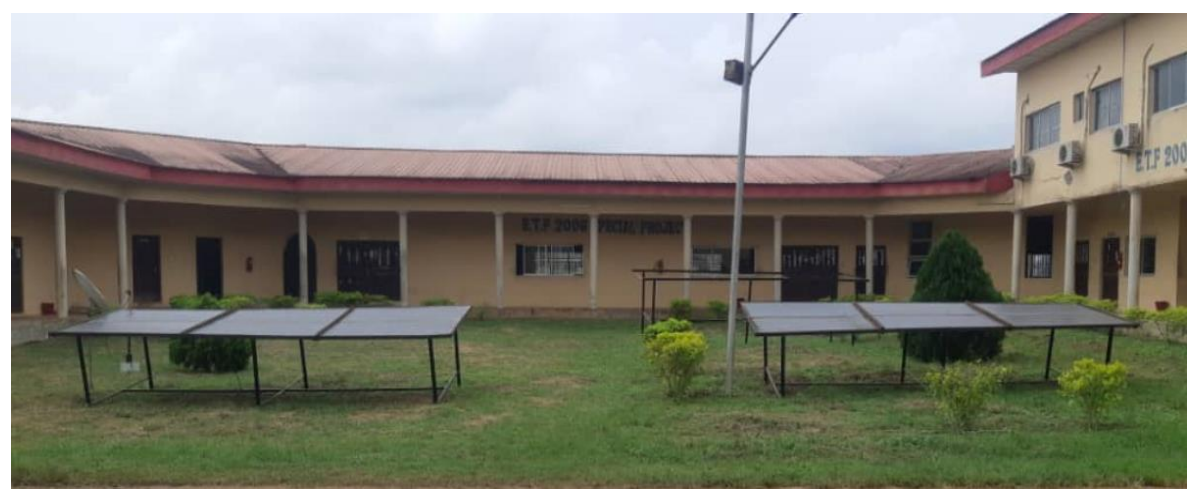

Fig. 2. The two Solar stand with solar panels used for the experiment.

\section{RESULTS AND DISCUSSION}

\subsection{Results}

In Table 1, the highest value of irradiance of 1355 watt $/ \mathrm{m}^{2}$ was recorded at $1.00 \mathrm{pm}$ with generated power at 377 watt. Increase in irradiance leads to increase in solar power generated but do not follow a linear pattern. It is observed that the power generated by each of the two solar panel varies as the solar panel placement affect the power generated as they are placed apart. The humidity level shows no effect on the solar power produced by the photovoltaic cells. The peak power was observed at $1.00 \mathrm{pm}$ of 377 watt.

Table 1. Irradiance, temperature and humidity in the first day readings.

\begin{tabular}{|l|l|l|l|l|l|l|l|l|l|}
\hline $\begin{array}{c}\text { Time } \\
(\mathrm{s})\end{array}$ & $\begin{array}{c}\text { Irradiance } \\
\left(\mathrm{W} / \mathrm{m}^{2}\right)\end{array}$ & $\begin{array}{c}\text { Temp } \\
\left({ }^{\circ} \mathrm{C}\right)\end{array}$ & $\begin{array}{c}\text { Humidity, } \\
\left(\mathrm{g} / \mathrm{m}^{3}\right)\end{array}$ & $\begin{array}{c}\text { Solar } \\
\text { Panel 1 } \\
\text { voltage, } \\
(\mathrm{V})\end{array}$ & $\begin{array}{c}\text { Solar } \\
\text { Panel 1 } \\
\text { Current, } \\
(\mathrm{A})\end{array}$ & $\begin{array}{c}\text { Solar } \\
\text { panel 1 } \\
\text { Power, } \\
(\mathrm{W})\end{array}$ & $\begin{array}{c}\text { Solar } \\
\text { Panel 2 } \\
\text { Voltage, } \\
(\mathrm{V})\end{array}$ & $\begin{array}{c}\text { Solar } \\
\text { panel 2 } \\
\text { Current, } \\
(\mathrm{A})\end{array}$ & $\begin{array}{c}\text { Solar } \\
\text { Panel 2 } \\
\text { Power, } \\
(\mathrm{W})\end{array}$ \\
\hline 8:00am & 18.00 & 23.00 & 91.00 & 33.30 & 0.11 & 3.66 & 31.30 & 0.11 & 3.44 \\
\hline 8:30am & 36.00 & 23.50 & 96.00 & 36.40 & 0.23 & 8.37 & 35.40 & 0.24 & 8.49 \\
\hline 9:00am & 65.00 & 24.00 & 92.00 & 39.60 & 0.57 & 22.52 & 39.50 & 0.62 & 24.49 \\
\hline 9:30am & 150.40 & 25.00 & 92.00 & 40.90 & 1.07 & 43.76 & 40.80 & 1.09 & 44.47 \\
\hline 10:00am & 191.10 & 25.00 & 92.00 & 41.30 & 1.53 & 63.19 & 41.40 & 1.67 & 69.14 \\
\hline 10:30am & 237.80 & 26.50 & 88.00 & 42.00 & 2.82 & 118.44 & 41.70 & 2.80 & 116.76 \\
\hline 11:00am & 158.00 & 25.00 & 92.00 & 39.10 & 0.82 & 32.06 & 39.10 & 0.78 & 30.50 \\
\hline 11:30am & 344.00 & 26.00 & 84.00 & 42.30 & 3.60 & 152.28 & 42.60 & 3.84 & 163.58 \\
\hline 12:00pm & 325.00 & 26.00 & 92.00 & 41.30 & 2.28 & 94.16 & 41.20 & 2.13 & 87.76 \\
\hline 12:30pm & 456.00 & 30.00 & 85.00 & 41.20 & 3.35 & 138.02 & 41.60 & 3.15 & 131.04 \\
\hline
\end{tabular}




\begin{tabular}{|l|l|l|l|l|l|l|l|l|l|}
\hline $01: 00 \mathrm{pm}$ & 1355.00 & 40.00 & 82.00 & 41.80 & 9.04 & 377.87 & 42.30 & 8.26 & 349.40 \\
\hline $01: 30 \mathrm{pm}$ & 494.00 & 29.00 & 92.00 & 41.20 & 3.66 & 150.79 & 41.50 & 3.56 & 147.74 \\
\hline $2: 00 \mathrm{pm}$ & 1011.00 & 35.00 & 87.00 & 42.90 & 8.60 & 368.94 & 42.30 & 8.41 & 355.74 \\
\hline $2: 30 \mathrm{pm}$ & 312.00 & 28.00 & 92.00 & 41.00 & 1.89 & 77.49 & 40.40 & 1.77 & 71.51 \\
\hline $3: 00 \mathrm{pm}$ & 277.00 & 27.50 & 88.00 & 41.70 & 2.02 & 84.23 & 41.60 & 2.18 & 90.69 \\
\hline $3: 30 \mathrm{pm}$ & 184.40 & 26.00 & 92.00 & 41.80 & 2.25 & 94.05 & 41.90 & 1.82 & 76.26 \\
\hline $4: 00 \mathrm{pm}$ & 191.60 & 27.00 & 92.00 & 41.00 & 2.37 & 97.17 & 41.50 & 1.82 & 75.53 \\
\hline
\end{tabular}

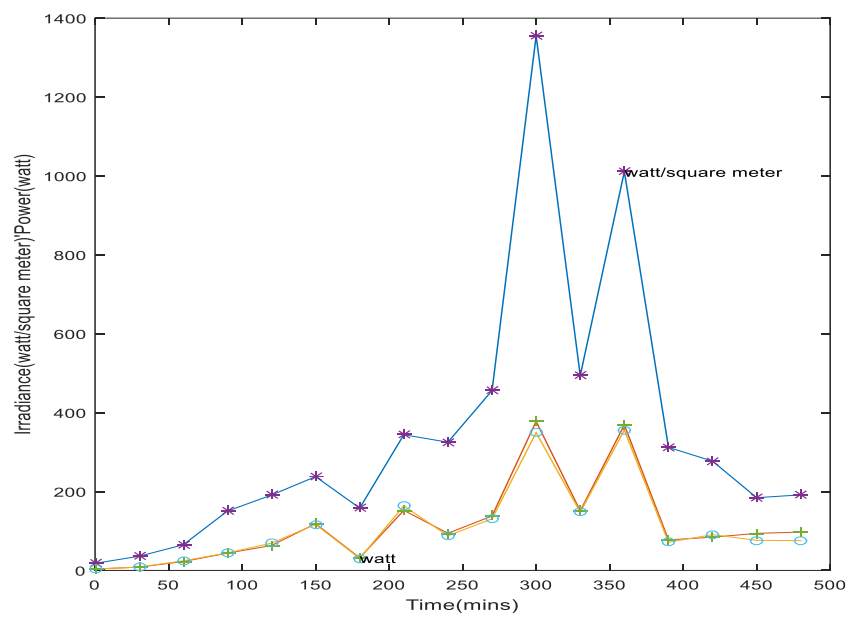

Fig. 3. Relationship between Irradiance and Power generated with time.

From the Figure 3, it is observed that increase in irradiance lead to an increase in solar power generated. Decrease in irradiance leads to a corresponding decrease in the solar power generated.

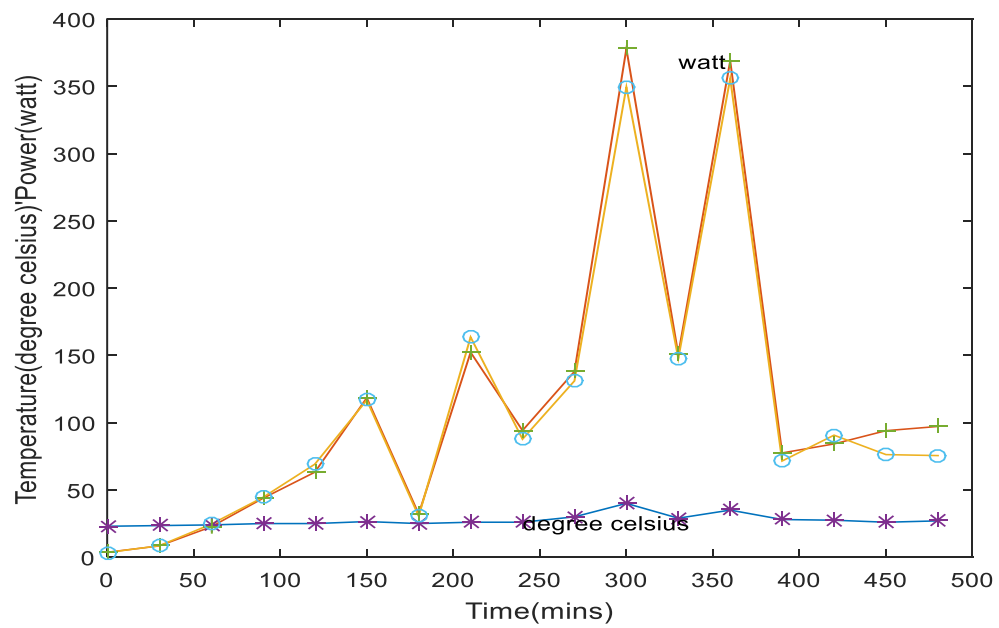

Fig. 4. Relationship between temperature and Power generated with time.

From Figure 4, it is observed that temperature does not have an effect on the solar power generated. From the shape of the graphs of power generated and temperature, a corresponding increase and decrease of the power generated do not reflect in the temperature plot. 


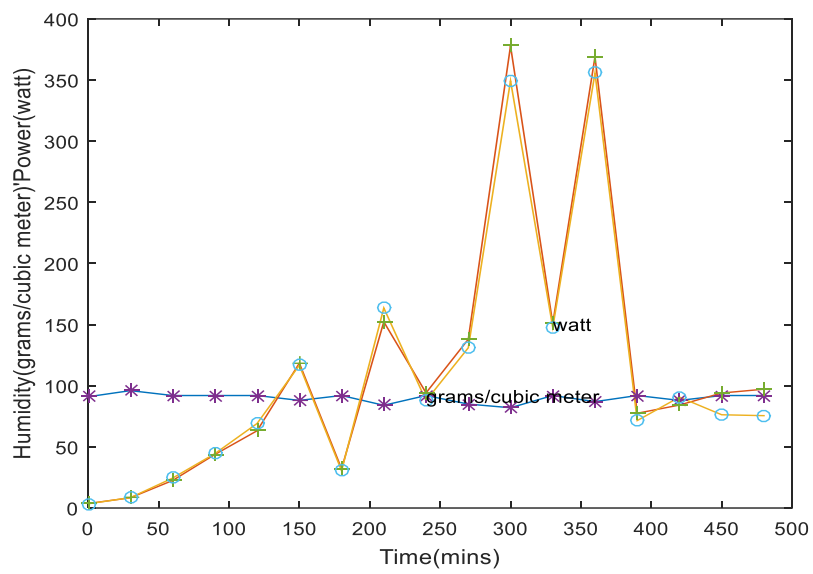

Fig. 5. Relationship between humidity and Power generated with time.

From Figure 5, it is observed that humidity does not have effect on the power generated. Here, changes in solar power generated are obtained with fairly constant humidity values.

From Table 2, it is observed that higher values of irradiance and temperature were recorded on day 2 compared to recordings in Table1 obtained on day 1; with a lesser power recorded for Table 2. Though they follow the same trend as increase in irradiance is accompanied by increase in power generated, it does not follow a linear pattern. The highest irradiance and temperature were obtained at 3:30 pm. More power was generated in the evening at 4:00 pm than at midday for Table 2 .

Table 2. Irradiance, temperature and humidity in the second day of readings.

\begin{tabular}{|c|l|l|l|l|l|l|l|l|l|}
\hline $\begin{array}{c}\text { Time, } \\
(\mathrm{s})\end{array}$ & $\begin{array}{c}\text { Irradiance, } \\
\left(\mathrm{W} / \mathrm{m}^{2}\right)\end{array}$ & $\begin{array}{c}\text { Temp, } \\
\left({ }^{\circ} \mathrm{C}\right)\end{array}$ & $\begin{array}{c}\text { Humidity, } \\
\left(\mathrm{g} / \mathrm{m}^{3}\right)\end{array}$ & $\begin{array}{c}\text { Solar } \\
\text { Panel 1 } \\
\text { voltage, } \\
(\mathrm{V})\end{array}$ & $\begin{array}{c}\text { Solar } \\
\text { Panel 1 } \\
\text { Current, } \\
(\mathrm{A})\end{array}$ & $\begin{array}{c}\text { Solar } \\
\text { panel 1 } \\
\text { Power, } \\
(\mathrm{W})\end{array}$ & $\begin{array}{c}\text { Solar } \\
\text { Panel 2 } \\
\text { Voltage, } \\
(\mathrm{V})\end{array}$ & $\begin{array}{c}\text { Solar } \\
\text { panel 2 } \\
\text { Current, } \\
(\mathrm{A})\end{array}$ & $\begin{array}{c}\text { Solar } \\
\text { Panel 2 } \\
\text { Power, } \\
(\mathrm{W})\end{array}$ \\
\hline 8:00am & 102.00 & 24.00 & 92.00 & 39.70 & 0.60 & 23.82 & 39.60 & 0.62 & 48.31 \\
\hline $8: 30 \mathrm{am}$ & 180.00 & 25.00 & 92.00 & 41.20 & 1.16 & 47.79 & 41.10 & 1.22 & 50.14 \\
\hline $9: 00 \mathrm{am}$ & 130.00 & 25.00 & 92.00 & 40.50 & 1.02 & 41.31 & 40.20 & 1.02 & 41.00 \\
\hline $9: 30 \mathrm{am}$ & 280.00 & 26.50 & 96.00 & 41.80 & 1.72 & 71.90 & 41.50 & 1.79 & 74.29 \\
\hline $10: 00 \mathrm{am}$ & 264.00 & 26.00 & 92.00 & 41.30 & 1.71 & 70.62 & 41.30 & 1.80 & 74.34 \\
\hline $10: 30 \mathrm{am}$ & 296.00 & 27.00 & 84.00 & 41.70 & 2.11 & 87.99 & 41.70 & 2.21 & 92.16 \\
\hline $11: 00 \mathrm{am}$ & 209.00 & 26.00 & 92.00 & 40.90 & 1.47 & 60.12 & 40.90 & 1.60 & 65.44 \\
\hline $11: 30 \mathrm{am}$ & 410.00 & 28.50 & 89.00 & 41.80 & 3.84 & 160.51 & 41.70 & 3.93 & 163.88 \\
\hline $12: 00 \mathrm{pm}$ & 393.00 & 28.00 & 92.00 & 41.90 & 3.11 & 130.31 & 41.70 & 3.19 & 133.02 \\
\hline $12: 30 \mathrm{pm}$ & 744.00 & 32.00 & 86.00 & 41.90 & 6.36 & 266.48 & 42.00 & 5.55 & 233.10 \\
\hline $01: 00 \mathrm{pm}$ & 381.00 & 28.00 & 92.00 & 40.20 & 3.30 & 132.66 & 40.10 & 3.37 & 135.14 \\
\hline $01: 30 \mathrm{pm}$ & 603.00 & 31.00 & 93.00 & 40.90 & 3.87 & 158.28 & 41.00 & 4.26 & 174.66 \\
\hline 2:00pm & 448.00 & 29.00 & 85.00 & 40.70 & 3.31 & 134.72 & 41.10 & 3.48 & 143.01 \\
\hline $2: 30 \mathrm{pm}$ & 439.00 & 29.00 & 92.00 & 41.40 & 4.12 & 170.57 & 41.60 & 4.09 & 170.14 \\
\hline $3: 00 \mathrm{pm}$ & 201.00 & 27.00 & 92.00 & 41.60 & 3.15 & 131.04 & 41.20 & 3.66 & 150.79 \\
\hline $3: 30 \mathrm{pm}$ & 1669.00 & 42.00 & 88.00 & 41.30 & 4.50 & 185.85 & 40.90 & 4.30 & 175.87 \\
\hline $4: 00 \mathrm{pm}$ & 1256.00 & 37.00 & 93.00 & 41.80 & 5.91 & 247.04 & 41.60 & 5.91 & 245.86 \\
\hline
\end{tabular}

For Table 3, it is observed that a higher value of irradiance does not lead to a much higher value of power generated. It is seen that at 3:30 pm, the irradiance was $1670 \mathrm{watt} / \mathrm{m}^{2}$, the solar power generation was 176 watt, but as the Irradiance reduces to $900 \mathrm{watt} / \mathrm{m}^{2}$ by $4.00 \mathrm{pm}$, the solar power was above $203 \mathrm{watt}$, the highest power generated.

Table 3. Irradiance, temperature and humidity in the third day of readings.

\begin{tabular}{|c|c|c|c|c|c|c|c|c|c|}
\hline $\begin{array}{c}\text { Time } \\
(\mathrm{s})\end{array}$ & $\begin{array}{c}\text { Irradiance } \\
\left(\mathrm{W} / \mathrm{m}^{2}\right)\end{array}$ & $\begin{array}{c}\text { Temp } \\
\left({ }^{\circ} \mathrm{C}\right)\end{array}$ & $\begin{array}{c}\text { Humidity } \\
\left(\mathrm{g} / \mathrm{m}^{3}\right)\end{array}$ & $\begin{array}{c}\text { Solar } \\
\text { Panel 1 } \\
\text { voltage, } \\
(\mathrm{V})\end{array}$ & $\begin{array}{c}\text { Solar } \\
\text { Panel 1 } \\
\text { Current, } \\
(\mathrm{A})\end{array}$ & $\begin{array}{c}\text { Solar } \\
\text { panel 1 } \\
\text { Power, } \\
(\mathrm{W})\end{array}$ & $\begin{array}{c}\text { Solar } \\
\text { Panel 2 } \\
\text { Voltage, } \\
(\mathrm{V})\end{array}$ & $\begin{array}{c}\text { Solar } \\
\text { panel 2 } \\
\text { Current, } \\
(\mathrm{A})\end{array}$ & $\begin{array}{c}\text { Solar } \\
\text { Panel 2 } \\
\text { Power, } \\
(\mathrm{W})\end{array}$ \\
\hline $8: 00 \mathrm{am}$ & 100.00 & 24.00 & 92.00 & 40.00 & 0.66 & 26.40 & 40.00 & 0.64 & 25.60 \\
\hline $8: 30 \mathrm{am}$ & 178.00 & 25.00 & 92.00 & 41.30 & 1.21 & 49.97 & 41.40 & 1.19 & 49.27 \\
\hline
\end{tabular}




\begin{tabular}{|l|l|l|l|l|l|l|l|l|l|}
\hline 9:00am & 127.00 & 25.00 & 84.00 & 40.30 & 0.91 & 36.67 & 40.70 & 1.02 & 41.51 \\
\hline 9:30am & 280.00 & 26.50 & 88.00 & 41.60 & 1.76 & 73.22 & 41.50 & 1.74 & 72.21 \\
\hline $10: 00 \mathrm{am}$ & 261.00 & 26.00 & 92.00 & 40.90 & 1.71 & 69.94 & 41.50 & 1.83 & 75.95 \\
\hline $10: 30 \mathrm{am}$ & 294.00 & 27.00 & 84.00 & 41.70 & 2.22 & 92.57 & 41.70 & 2.21 & 92.16 \\
\hline $11: 00 \mathrm{am}$ & 207.00 & 27.00 & 92.00 & 41.30 & 1.63 & 67.32 & 41.20 & 1.64 & 67.57 \\
\hline $11: 30 \mathrm{am}$ & 411.00 & 28.00 & 84.00 & 42.00 & 3.66 & 153.72 & 42.20 & 3.65 & 154.03 \\
\hline $12: 00 \mathrm{pm}$ & 393.00 & 28.00 & 92.00 & 41.70 & 3.17 & 132.19 & 41.70 & 3.16 & 131.77 \\
\hline $12: 30 \mathrm{pm}$ & 739.00 & 32.00 & 93.00 & 42.00 & 5.55 & 233.10 & 42.00 & 5.54 & 232.68 \\
\hline $01: 00 \mathrm{pm}$ & 379.00 & 28.00 & 92.00 & 40.60 & 3.34 & 135.60 & 40.60 & 3.33 & 135.20 \\
\hline $01: 30 \mathrm{pm}$ & 600.00 & 31.00 & 93.00 & 41.20 & 4.15 & 170.98 & 41.00 & 4.26 & 174.66 \\
\hline $2: 00 \mathrm{pm}$ & 448.00 & 29.00 & 92.00 & 41.10 & 3.31 & 136.04 & 41.00 & 3.30 & 135.30 \\
\hline $2: 30 \mathrm{pm}$ & 439.00 & 29.00 & 85.00 & 41.60 & 4.09 & 170.14 & 41.60 & 4.10 & 170.56 \\
\hline $3: 00 \mathrm{pm}$ & 205.00 & 27.00 & 92.00 & 41.30 & 3.62 & 149.51 & 41.40 & 3.60 & 149.04 \\
\hline 3:30pm & 1670.00 & 42.00 & 88.00 & 40.60 & 4.35 & 176.61 & 40.90 & 4.31 & 176.28 \\
\hline $4: 00 \mathrm{pm}$ & 900.00 & 34.00 & 86.00 & 40.70 & 5.00 & 203.50 & 41.00 & 5.05 & 207.05 \\
\hline
\end{tabular}

For Table 4, it is observed that a higher value of irradiance does not lead to a much higher value of power generated, and in the same time is similar to the second day of readings. At 3:30 pm, the irradiance was

1670 watt $/ \mathrm{m}^{2}$, the solar power generation was 176 watt, but as the Irradiance reduces to $900 \mathrm{watt} / \mathrm{m}^{2}$ by $4.00 \mathrm{pm}$, the solar power was above 207 watt, the highest power generated.

Table 4. Irradiance, temperature and humidity fourth day readings

\begin{tabular}{|c|l|l|l|l|l|l|l|l|l|}
\hline $\begin{array}{c}\text { Time } \\
(\mathrm{s})\end{array}$ & $\begin{array}{c}\text { Irradiance } \\
\left(\mathrm{W} / \mathrm{m}^{2}\right)\end{array}$ & $\begin{array}{c}\text { Temp } \\
\left({ }^{\circ} \mathrm{C}\right)\end{array}$ & $\begin{array}{c}\text { Humidity } \\
\left(\mathrm{g} / \mathrm{m}^{3}\right)\end{array}$ & $\begin{array}{c}\text { Solar } \\
\text { Panel 1 } \\
\text { voltage, } \\
(\mathrm{V})\end{array}$ & $\begin{array}{c}\text { Solar } \\
\text { Panel 1 } \\
\text { Current, } \\
(\mathrm{A})\end{array}$ & $\begin{array}{c}\text { Solar } \\
\text { panel 1 } \\
\text { Power, } \\
(\mathrm{W})\end{array}$ & $\begin{array}{c}\text { Solar } \\
\text { Panel 2 } \\
\text { Voltage, } \\
(\mathrm{V})\end{array}$ & $\begin{array}{c}\text { Solar } \\
\text { panel 2 } \\
\text { Current, } \\
(\mathrm{A})\end{array}$ & $\begin{array}{c}\text { Solar } \\
\text { Panel 2 } \\
\text { Power, } \\
(\mathrm{W})\end{array}$ \\
\hline $8: 00 \mathrm{am}$ & 84.00 & 25.00 & 92.00 & 39.30 & 0.58 & 22.79 & 38.20 & 0.57 & 21.77 \\
\hline $8: 30 \mathrm{am}$ & 39.00 & 25.00 & 92.00 & 36.40 & 0.26 & 9.46 & 36.10 & 0.26 & 9.39 \\
\hline $9: 00 \mathrm{am}$ & 43.00 & 25.00 & 84.00 & 37.20 & 0.31 & 11.53 & 36.90 & 0.32 & 11.81 \\
\hline $9: 30 \mathrm{am}$ & 51.00 & 25.00 & 92.00 & 37.60 & 0.33 & 12.41 & 37.50 & 0.36 & 13.50 \\
\hline $10: 00 \mathrm{am}$ & 158.00 & 26.00 & 84.00 & 40.80 & 1.07 & 43.66 & 40.70 & 1.11 & 45.18 \\
\hline $10: 30 \mathrm{am}$ & 156.00 & 26.00 & 92.00 & 40.40 & 0.96 & 38.78 & 40.50 & 1.08 & 43.74 \\
\hline $11: 00 \mathrm{am}$ & 295.00 & 27.00 & 84.00 & 41.50 & 1.91 & 79.27 & 41.40 & 1.97 & 81.56 \\
\hline $11: 30 \mathrm{am}$ & 548.00 & 28.00 & 92.00 & 42.00 & 3.50 & 147.00 & 42.30 & 3.40 & 143.82 \\
\hline $12: 00 \mathrm{pm}$ & 230.00 & 28.00 & 85.00 & 41.00 & 1.65 & 67.65 & 41.00 & 1.65 & 67.65 \\
\hline $12: 30 \mathrm{pm}$ & 138.00 & 27.00 & 92.00 & 39.80 & 1.00 & 39.80 & 39.50 & 1.01 & 39.90 \\
\hline $01: 00 \mathrm{pm}$ & 190.00 & 26.00 & 92.00 & 40.60 & 1.02 & 41.72 & 41.00 & 1.04 & 42.64 \\
\hline $01: 30 \mathrm{pm}$ & 370.00 & 26.00 & 84.00 & 41.90 & 1.92 & 80.45 & 41.80 & 1.98 & 81.97 \\
\hline $2: 00 \mathrm{pm}$ & 368.00 & 25.00 & 84.00 & 42.60 & 2.74 & 116.72 & 42.40 & 2.71 & 114.90 \\
\hline $2: 30 \mathrm{pm}$ & 230.00 & 25.00 & 96.00 & 41.60 & 1.31 & 54.50 & 41.60 & 1.30 & 54.47 \\
\hline $3: 00 \mathrm{pm}$ & 261.00 & 24.00 & 96.00 & 42.00 & 1.56 & 65.52 & 41.90 & 1.52 & 63.69 \\
\hline $3: 30 \mathrm{pm}$ & 191.00 & 25.00 & 92.00 & 41.40 & 1.22 & 50.51 & 41.10 & 1.21 & 49.73 \\
\hline $4: 00 \mathrm{pm}$ & 198.00 & 25.00 & 92.00 & 40.40 & 1.10 & 44.44 & 40.70 & 1.06 & 43.14 \\
\hline
\end{tabular}

\subsection{Discussions}

When the irradiance level of light changes, the number of photons and energy entering the PV device changes, and the number of electrons released, transformed to electrical energy also changes. Changes in irradiance significantly affect output current but have a smaller effect on the voltage. The current is directly proportional to light intensity, and the voltage varies more slowly in a logarithmic relationship.

The operating temperatures of solar cells are not important in that higher operating temperatures do not affect power outputs. Humidity levels do not affect the solar power generated but lead to corrosion of the supporting metal frames used as supporting structures when placed on a field.

\section{CONCLUSION}

This paper investigated the effect of temperature, humidity and irradiance on solar power generation. Result obtained showed that power generated by the solar cells depend majorly on solar irradiance. Surrounding 
temperature and humidity do not significantly affect solar power generated from the photovoltaic cells. It was observed that high temperatures and higher humidity levels accelerate the corrosion process on the supporting metal frames used as the solar stand. It is suggested that supporting structures for solar cells built for the tropical region should be covered with less corrosive materials. Placement of the solar stand affect the power generated as the power from the two solar stands differs slightly mainly due to the shadow of the building on the solar panels. It is also suggested that solar panels for solar power generation should be placed in an open field with no building close-by or more conveniently, on the roof of the building.

\section{REFERENCES}

[1] Reece, W., The History of Solar Power, 2015; Retrieved from http://www.fuelfromthesun.com (accessed on 01. 03. 2020).

[2] Ike, C.U., The effect of temperature on the performance of a photovoltaic solar system in Eastern Nigeria, International Journal of Engineering and Science, vol. 3, no. 12, 2013, p. 10-14.

[3] Rani, P.S., Giridhar, S.M., Prasad, S.R., Effect of temperature and irradiance on solar module performance, Journal of Electrical and Electronics Engineering, vol. 13, no. 2, 2018, p. 36-40.

[4] Abdul, R.P., Damhuji, R., Kharudin, A., Muhammad, Z. M., Ahmed, N.A., Moneer, A. F., Solar irradiance measurement instrumentation and power solar generation forecasting based on artificial neural networks (ANN): A review of five years research trend, Science of the Total Environment, vol. 715, no. 1, 2020.

[5] Soumyabrata, D., Florian, M.S., Yee, H. L., Stefan W., Estimating solar irradiance using sky images. Atmospheric Measurement Techniques, no. 12, 2019, p. 5417-5429.

[6] Pradham A., Ali, S.M., Jena C., Analysis of solar PV cell Performance with changing irradiance and temperature, International Journal of Engineering and Computer Science. vol. 2, no. 1, 2013, p. 214-220.

[7] Thomas, H., Ana, G., Estimating PV module performance over large geographical regions: the role of irradiance, air temperature, wind speed and solar spectrum, Energies, vol. 8, 2015, p. 5159-5181.

[8] Musanga, L.M., Barasa, W.H., Maxwell, M., The effect of irradiance and temperature on the performance of monocrystalline silicon solar module in Kakamega, Physical Science International Journal, vol. 19, no. 4, 2018 , p. $1-9$. 